Jurnal OFFSHORE, Volume 2 No. 1 Juni 2018 : 1 - 9 ; e -ISSN : 2549-8681

\title{
PEMODELAN INTENSITAS REKAHAN PADA FRACTURED BASEMENT RESER VOIR DENGAN PENDEKATAN KONSEP GEOLOGI MENGGUNAKAN ANALISIS KUALITATIF DI CEKUNGAN SUMATRA TENGAH
}

\author{
Muchamad Ocky Bayu Nugroho, Carolus Prasetyadi, Teguh Jatmiko \\ Jurusan Teknik Geologi, Fakultas Teknologi Mineral, UPN "Veteran" Yogyakarta \\ Correspending author email : bayu.ocky@gmail.com
}

\begin{abstract}
Abstrak
Lokasi Penelitian terletak di Selat Malaka dan termasuk dalam Cekungan Sumatra Tengah. Secara stratigrafi, Batuan Dasar Cekungan Sumatra Tengah berumur Pra Tersier dengan litologi batuan sedimen yang termalihkan atau metasedimen. Berdasarkan data sumur pemboran, batuan dasar di lokasi penelitian secara umum berupa kuarsit dan filit. Rekahan pada batuan dasar dikontrol oleh periode tektonik regional yang mempengaruhi Sumatra. Sesar-sesar yang terbentuk berarah umum Utara Barat Laut - Selatan Tenggara (NNW - SSE), hasil dari fase tektonik selama Paleogen hingga Neogen yang menghasilkan morfologi batuan dasar beragam akibat adanya horst graben dan half graben. Morfologi tinggian adalah yang berpotensi menjadi reservoir karena batuan induk yang terletak lebih rendah akan memungkinkan migrasi hidrokarbon. Identifikasi rekahan batuan dasar dianalisa berdasarkan data pemboran sumur dan seismik. Intensitas rekahan dibangun berdasarkan model dengan pendekatan 4 parameter geologi yaitu intensitas rekahan dengan jarak dari bidang sesar, intensitas rekahan dengan pucak antiklin, intensitas rekahan dengan jarak dari permukaan batuan dan dibantu dengan atribut seismik. Nilai intensitas yang memungkinkan terbentuk rekahan adalah $0,3-1$.
\end{abstract}

Kata Kunci : Batuan Dasar, Fractured, Reservoir

\section{Pendahuluan}

Reservoir rekahan batuan dasar atau yang sering disebut Fractured Basement Reservoir merupakan reservoir dimana hidrokarbon terperangkap pada rekahan ekstensi di batuan dasar (basement) yang umumnya berupa batuan kristalin (Sircar, 2004). Reservoir ini sudah cukup lama dikembangkan di Indonesia dan beberapa tempat sudah terbukti berproduksi, seperti di Lapangan Sumpal Cekungan Sumatra Selatan. Pemahaman dasar tentang resevoar batuan dasar ini tentunya akan sangat berbeda dengan reservoir konven-sional seperti pada batuan silisiklastik dan karbonat. Konsep tektonik dan struktur geologi yang baik memiliki peran utama dalam identifikasi pembentukan rekahan yang mengerucut pada intensitas, permeabilitas dan porositas. Penelitian ini mencoba menelisik potensi hidrokarbon pada batuan dasar di Cekungan Sumatra Tengah dengan menggunakan data sumur pemboran konvensional dan seismik 3D dengan pendekatan konsep geologi dan analisis kualitatif serta kuantitatif yang menghasilkan suatu model reservoir.

\subsection{Tatanan Geologi}

Heidrick dan Aulia (1993) menyatakan bahwa deformasi yang terjadi di Cekungan Sumatra Tengah dapat dibagi menjadi 4 fase utama seperti dapat dilihat pada Gambar 1, yaitu:

a. Fase deformasi Pre-Eosen (F0) yang ditandai oleh elemen struktur yang terdapat pada batuan dasar. Pada fase ini batuan dasar mengalami metamorfisme, pengangkatan, perlipatan, pen- sesaran serta intrusi granit. Adanya pengangkatan tersebut menghasilkan tinggian-tinggian sebagai batas yang penting pada pengendapan selanjutnya. Pada kelompok Malacca, intrusi granodiorit, kuarsit dan filit.

b. Fase (F1) berupa rifting yang terjadi pada kala Eosen-Oligosen. Episode F1 menghasilkan gaya transtensional hampir di seluruh lempeng mikro Sunda. Gaya ini menyebabkan terbentuknya rangkaian geometri graben dan half graben. Fase ini juga merupakan penyebab terbentuknya sesar-sesar normal berarah utara dan timurlaut dan terisi oleh sedimen klastik darat dan sedimen lakustrin dengan ketebalan yang berbeda-beda.

c. Fase (F2) berupa sag phase tectonism yang terjadi pada kala Oligosen Atas. Pada tahap ini terjadi subsidence dan transgresi pada cekungan, gaya kompresi hanya terjadi setempatsetempat membentuk sesar-sesar dan lipatan yang diikuti penurunan muka air laut global, sehingga membentuk morfologi yang relative datar pada Formasi Pematang dan batuan dasar yang tersingkap.

d. Fase (F3) merupakan fase kompresi yang terjadi pada Kala Miosen Tengah. Pada fase ini terjadi pembalikan struktur (structural inversion) akibat gaya kompresi menghasilkan struktur reverse dan thrust fault sepanjang jalur wrench fault yang terbentuk sebelumnya. Fase ini berhubungan dengan pengangkatan regional, busur vulkanisme utama dan sesar geser dekstral di sepanjang Bukit Barisan (sesar besar Sumatra) serta gaya kompresi 


\section{PEMODELAN INTESITAS REKAHAN PADA FRACTURED BASEMENT RESERVOIR DENGAN PENDEKATAN KONSEP GEOLOGI MENGGUNAKAN ANALISIS KUALITATIF DI CEKUNGAN SUMATRA TENGAH}

yang ada di sepanjang Cekungan Sumatra

Utara dan Sumatra Tengah.

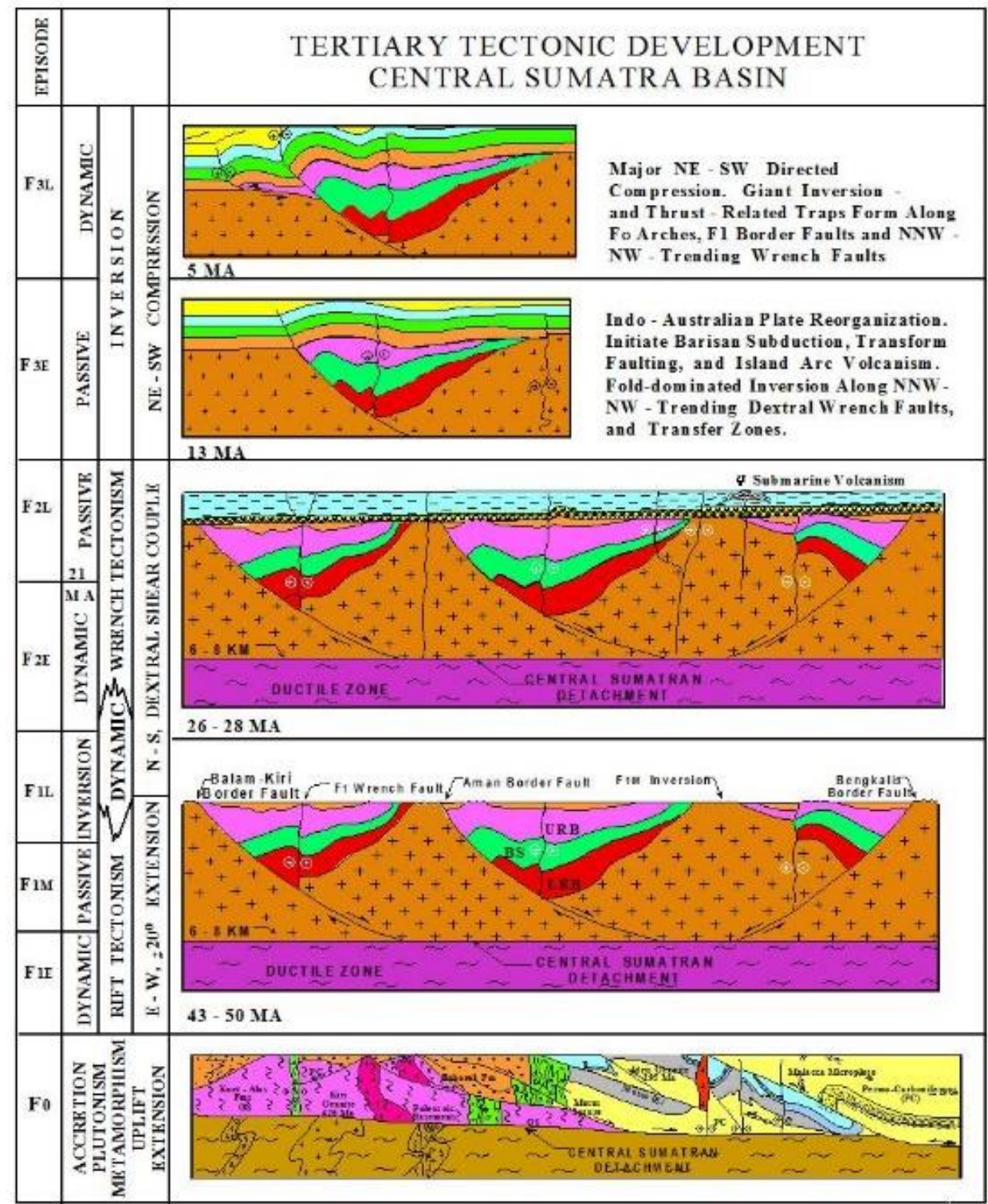

Gambar 1. Evolusi tektonik Cekungan Sumatra Tengah

(Heidrick \& Aulia, 1993)

\section{Metodologi}

Data - data yang digunakan pada penelitian ini adalah 3 data sumur dan sebuah data 3D seismic cube yang mencakup daerah penelitian. Data tersebut akan dianalisa secara kualitatif dan kuantitatif. Analisa kualitatif mencakup identifikasi rekahan di batuan dasar dengan menggunakan wireline log, mudlog dan data pemboran. Data seismik mendukung dalam identifikasi geometri dan pelamparan dari batuan dasar. Hasil analisa kualitatif tersebut akan di integrasikan dengan aplikasi teori dan konsep geologi pada daerah telitian yang diproses dengan bantuan perangkat lunak, sehingga akan didapatkan hasil visualisasi atau model geologi untuk memudahkan pemahaman pemboran. Data seismik mendukung dalam identifikasi geometri dan pelamparan dari batuan dasar. Hasil analisa kualitatif tersebut akan di integrasikan dengan aplikasi teori dan konsep geologi pada daerah telitian yang diproses dengan bantuan perangkat lunak, sehingga akan didapatkan hasil visualisasi atau model geologi untuk memudahkan pemahaman.

\section{Hasil dan Pembahasan \\ 3.1 Identifikasi Litologi}

Identifikasi litologi batuan dasar dilakukan secara kuaitatif dengan data wireline log dan 
mudlog dari ketiga sumur. Berdasarkan data mudlog interval batuan dasar diperkirakan pada kedalaman sekitar 6000ft TVDSS hingga 6400ft TVDSS yang tersusun atas litologi berupa batuan metasedimen seperti kuarsit dan filit. Visualisasi dari wireline log juga mendukung adanya perubahan litologi dengan berubahnya log densitas dan log sonic menjadi lebih tinggi secara signifikan. Hal ini menunjukan adanya perubahan nilai densitas batuan, dari nilai densitas untuk batuan sedimen menjadi nilai densitas untuk batuan kristalin (metasedimen). Berdasarkan ketiga sumur WO-4, WO-5 dan WO-6 memiliki litologi batuan dasar yang sama dan dapat ditarik korelasi dapat dilihat pada Gambar 2

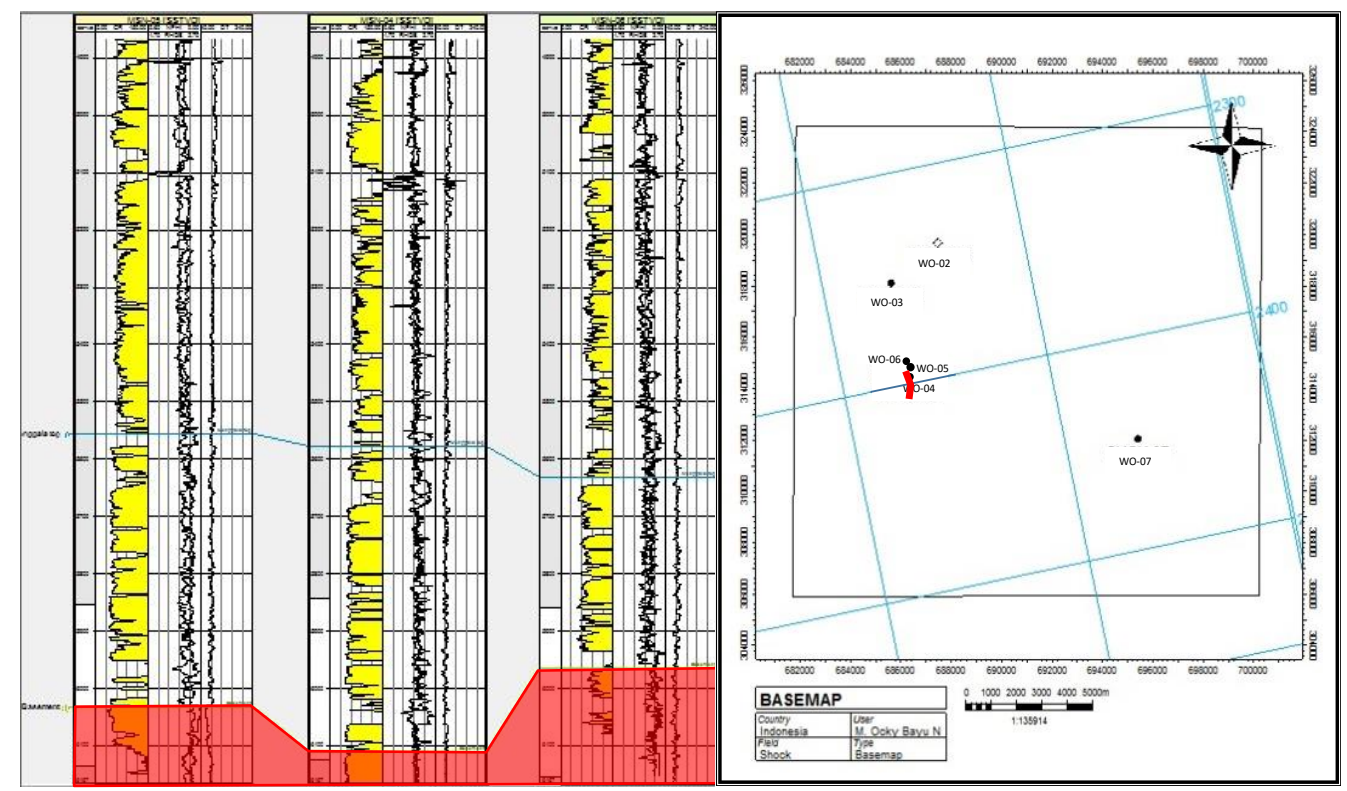

Gambar 2. Korelasi Struktur batuan dasar

\subsection{Idenfikasi Rekahan}

Identifikasi rekahan difokuskan pada zona batuan dasar yang dilakukan secara kualitatif berdasarkan data wireline log, mudlog dan didukung oleh data operasi pemboran. Berdasarkan data wireline log yang ditunjukan dengan perubahan nilai pada log resistivity yang mengecil, mencirikan keberadaan suatu rekahan karena batuan yang terkena rekahan akan lebih sulit menghantarkan arus listrik, untuk pola log density (RHOB) yang mengalami perubahan nilai yang mengecil dimana batuan yang terkena rekahan akan mengalami penurunan densitas. Selain itu didukung juga dengan penampakan nilai log sonic yang membesar, menandakan indikasi rekahan karena gelombang lebih lama terekam akibat penyerapan oleh daerah hancuran (rekahan).

\subsection{Identifikasi Hidrokarbon}

Identifikasi hidrokarbon dilakukan secara kualitatif dengan menggunakan data log Neutron dan Density yang dilihat dari crossover (penyilangan) kedua log pada nilai yang kecil. Selain itu didukung adanya kandungan hidrokarbon berupa gas yang ditunjukan dengan presentase gas yang muncul saat pengeboran. Di salah satu sumur yaitu sumur WO-06 dilakukan tes sumur dimana meng-hasilkan $732 \mathrm{MSCF} /$ day untuk gas dan 200 BO/day untuk minyak.

\subsection{Interpretasi Seismik dan Geometri Batuan Dasar}

Interpretasi seismik bertujuan untuk mengetahui kedalaman, morfologi dan geometri dari batuan dasar di daerah penelitian. Interpretasi seismik diawali dengan mengikat data sumur dengan data seismik menggunakan data checkshot. Tahap berikutnya adalah dengan melakukan inter-pretasi horizon untuk top batuan dasar dan interpretasi sesar yang berkembang di daerah penelitian dapat dilihat pada Gambar 3 . Berdasarkan hasil inter-pretasi tersebut dibangun peta struktur kedalaman permukaan yang menjadi 


\section{PEMODELAN INTESITAS REKAHAN PADA FRACTURED BASEMENT RESERVOIR DENGAN PENDEKATAN KONSEP GEOLOGI MENGGUNAKAN ANALISIS KUALITATIF DI CEKUNGAN SUMATRA TENGAH}

dasar pembuatan geo-metri batuan dasar di daerah penelitian.

Struktur geologi pada daerah penelitian didominasi oleh sesar - sesar yang berarah dominan NNE-SSW. Sesar tersebut merupakan sesar normal yang telah mengalami reaktivasi menjadi
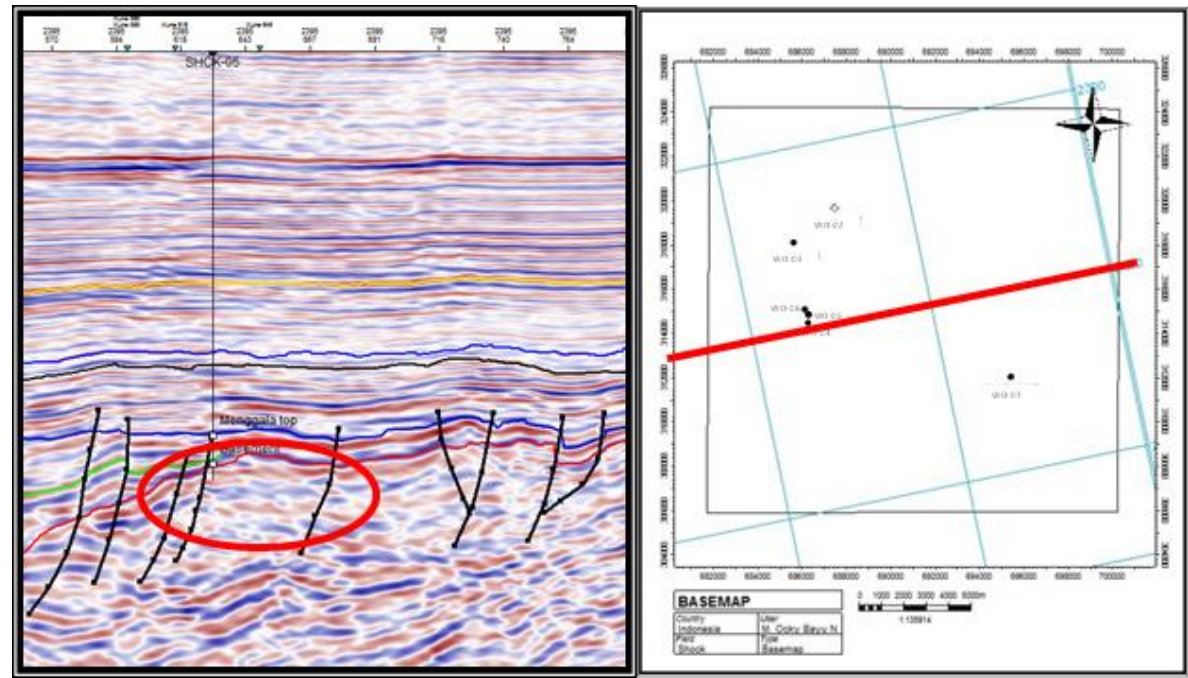

Gambar 3. Penampang seismik berarah Barat - Timur

(lingkaran merah menunjukan zona potensi fracture)

\subsection{Identifikasi Intesitas rekahan}

Intensitas rekahan merupakan jumlah nilai dari banyaknya rekahan yang kemungkinan terbentuk. Intensitas rekahan sangat penting dalam reservoir ini karena akan berhubungan langsung dengan permeabilitas dan porositas. Secara umum, jika intensitas rekahan semakin tinggi maka permeabilitas dan porositas akan semakin tinggi juga, akan tetapi harus mempertimbangkan aspek rekahan yang terbuka atau yang tertutup. Identifikasi rekahan yang terbuka dan tertutup dapat di perkirakan dan dimodelkan dengan sesar naik atau sesar geser akibat adanya dua proses tektonik yang mempengaruhi (Heidrik \& Aulia, 1992).

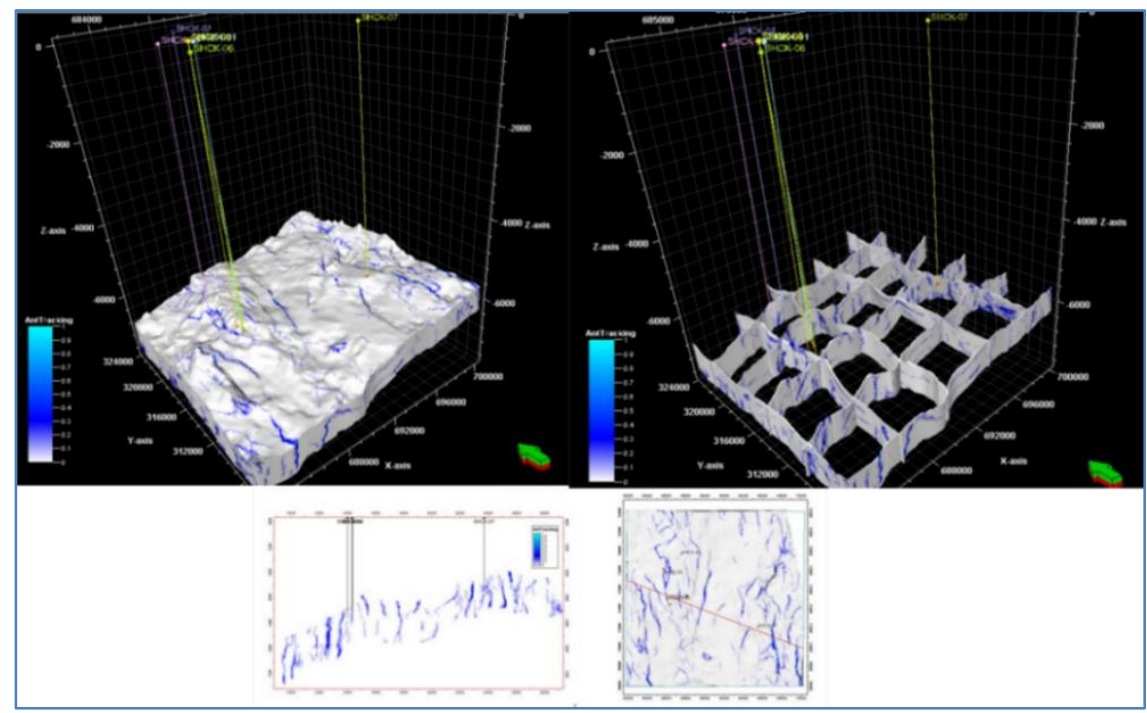

Gambar 4. Atribut seismik Ant-Tracking 
Atribut ant-tracking merupakan salah satu jenis atribut seismik yang berguna secara maksimal pada seismik 3D. Pada dasarnya atribut ini menggabungkan dan memfilter beberapa atribut seperti chaos dan variance yang berfungsi menguatkan ketidakmenerusan dan batas amplitudo (Cox, 2007). Ketidakmenerusan ini akan teridentifikasi sebagai struktur sesar (Gambar 4) dan dapat menguatkan dalam interpretasi sesar.

Intensitas rekahan terhadap jarak dengan zona/ bidang sesar.

Hubungan sesar dengan rekahan sangat dekat, baik dalam mekanisme pembentukan maupun jenisnya. Menurut Van Golf (1982). Sesar dan rekahan mempunyai beberapa asumsi antara lain :

a. Sesar dan rekahan mempunyai orientasi gaya yang sama.

b. Orientasi rekahan dapat diketahui dari orientasi sesar.

c. 3 arah gaya dalam pembentukan rekahan dapat diprediksi dari pola sesar.

d. Sesar normal dapat mempunyai pendekatan untuk mengetahui perkembangan relatif 2 shear fracture.

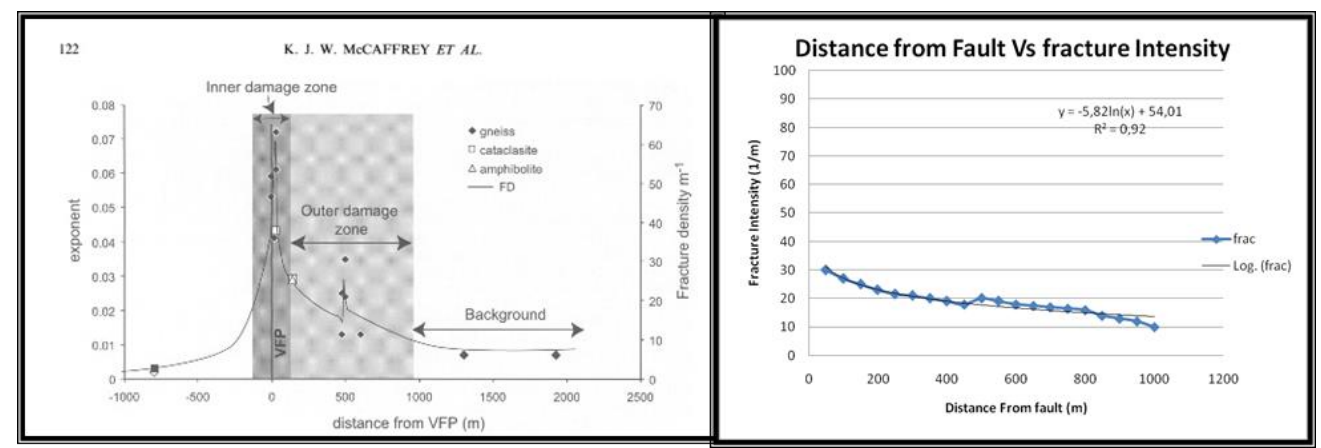

Gambar 5. Jarak Versus Intensitas Rekahan Pada Batuan Kristalin dan Kurva Persamaan pada Daerah Penelitian

(Mc Caffrey, 2003)

Secara umum sesar terbentuk di zona - zona lemah atau zona yang sensitif dalam merespon gaya / tektonik. Zona lemah berpotensi dalam pembentukan rekahan. Sesar - sesar pada lapangan ini sudah mengalami beberapa fase tektonik sehingga banyak mempengaruhi pembentukan rekahan sehingga intensitas rekahan akan banyak dipengaruhi oleh kehadiran sesar. Mc Caffrey pada tahun 2003 mencoba menghubungkan intensitas rekahan dengan jarak dari bidang sesar pada batuan kristalin ditampilkan pada kurva (Gambar 5) sehingga dapat ditarik suatu persamaan hubungan.

Persamaan tersebut diaplikasikan dan dikalkulasikan kedalam model 3 dimensi dan mendapat hasil berupa intensitas rekahan yang ditunjukan dengan warna dan jarak nilai 0-1. 0 yang berarti intensitas rendah dan 1 yang berarti intensitas tinggi (Gambar 6).

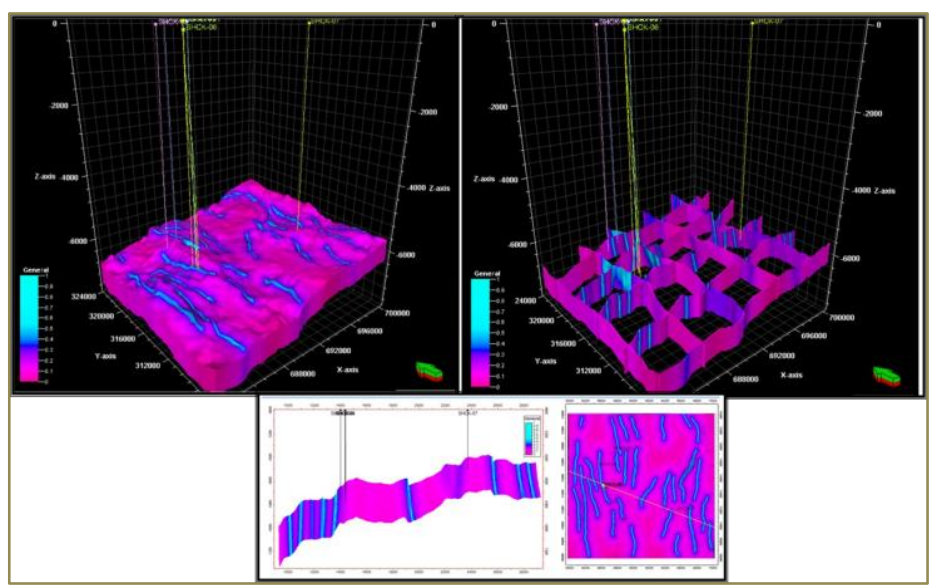

Gambar 6. Peta dan Penampang Model Fault related 


\section{PEMODELAN INTESITAS REKAHAN PADA FRACTURED BASEMENT RESERVOIR DENGAN PENDEKATAN KONSEP GEOLOGI MENGGUNAKAN ANALISIS KUALITATIF DI CEKUNGAN SUMATRA TENGAH}

\subsection{Intensitas rekahan terhadap struktur lipatan}

Fase Kompresi F3 pada kala Miosen hingga Recent sangat berpengaruh dalam pembentukan struktur lipatan di Sumatra Tengah. Gaya tersebut sangat berpengaruh pada formasi - formasi pengisi cekungan juga pada batuan dasar. Batuan dasar akan mengalami reaktivasi sesar menjadi sesar geser (Transtension ataupun Transpression).
Pola transpression akan membentuk struktur positif yang memiliki pola seperti lipatan dipuncak. Hal ini akan membentuk suatu sistem rekahan yang dipengaruhi oleh lipatan. Hubungan intensitas rekahan dengan jarak dari puncak lipatan telah dimodelkan oleh (Murray, 1968) dan digunakan sebagai untuk mengetahui persamaan kurva hubungan tersebut (Gambar 7).

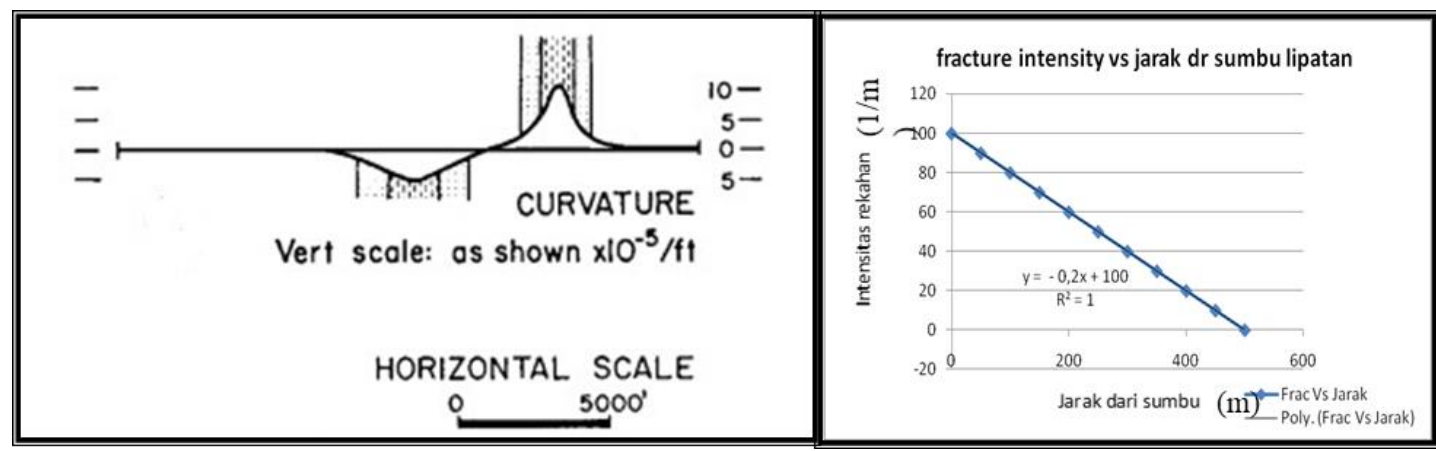

Gambar 7. Model Intensitas Rekahan Berdasarkan Bentuk Kurva Lipatan dan Kurva Persamaan Pada Daerah Penelitian

(Murray ,1968)

Berdasarkan persamaan hubungan lipatan dan intensitas rekahan telah diaplikasikan kedalam model 3 dimensi dan mendapat hasil berupa intensitas rekahan yang ditunjukan dengan warna dan jarak nilai 0-1. 0 yang berarti intensitas rendah dan 1 yang berarti intensitas tinggi dapat dilihat pada Gambar 8 .

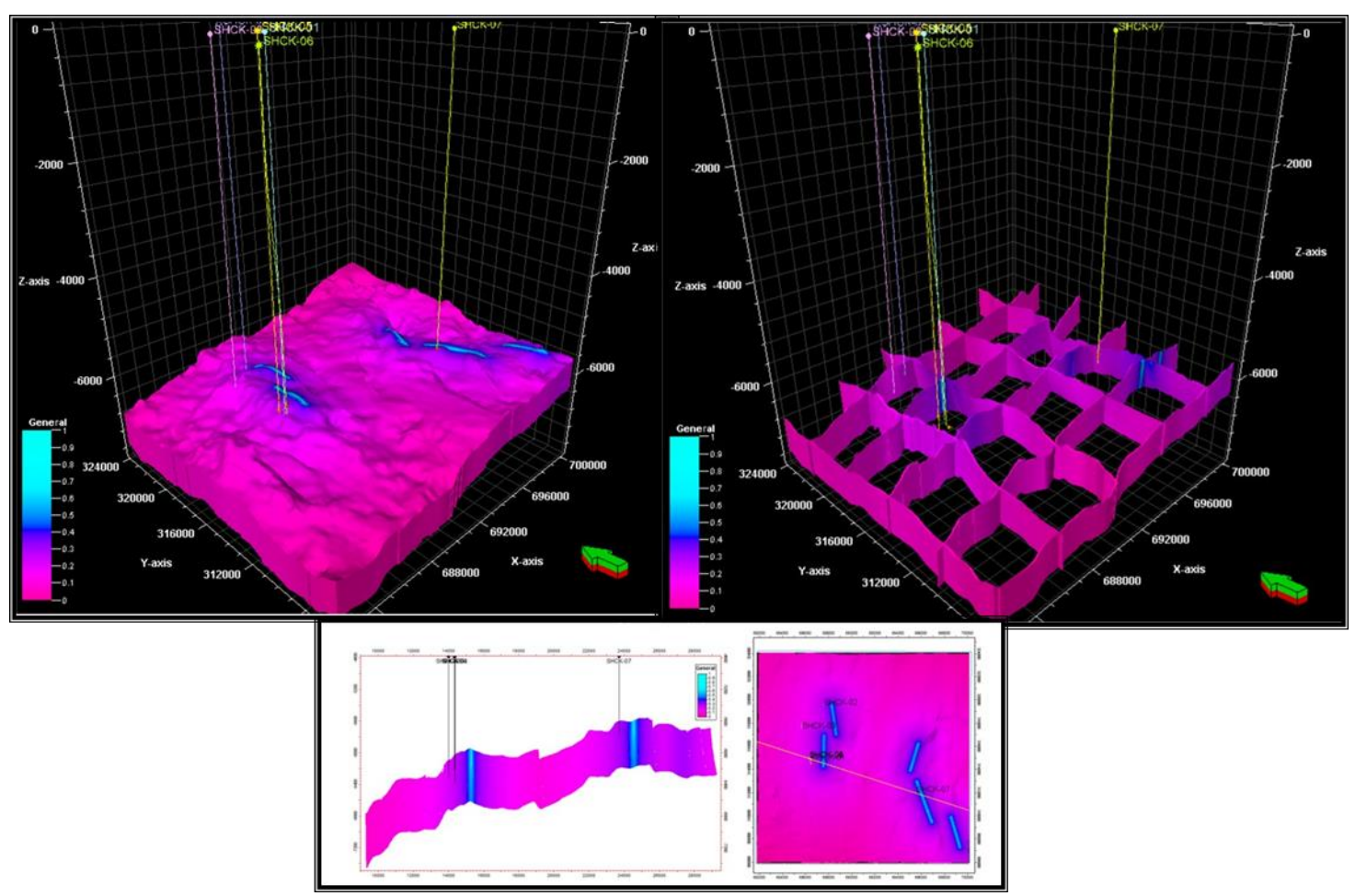

Gambar 8. Peta dan Penampang Model Fold related 


\subsection{Hubungan dengan kedalaman / depth related}

Faktor lain selain tektonisme dalam pembentukan rekahan adalah karakter batuan, salah satunya adalah ketebalan batuan. Dalam penelitian ini, ketebalan lapisan diartikan juga sebagai jarak kedalaman dari permukaan batuan, karena fokus penelitian adalah batuan dasar dimana merupakan batuan kristalin. Secara teoritis inten-sitas rekahan akan berbanding terbalik dengan tebal lapisan/ jarak dari permukaan batuan (Price, 1966). Intensitas rekahan ini menggunakan parameter hasil penelitian pada daerah yang sejenis kemudian dikonversikan ke dalam kurva dengan persamaan garis dapat dilihat pada Gambar 9.

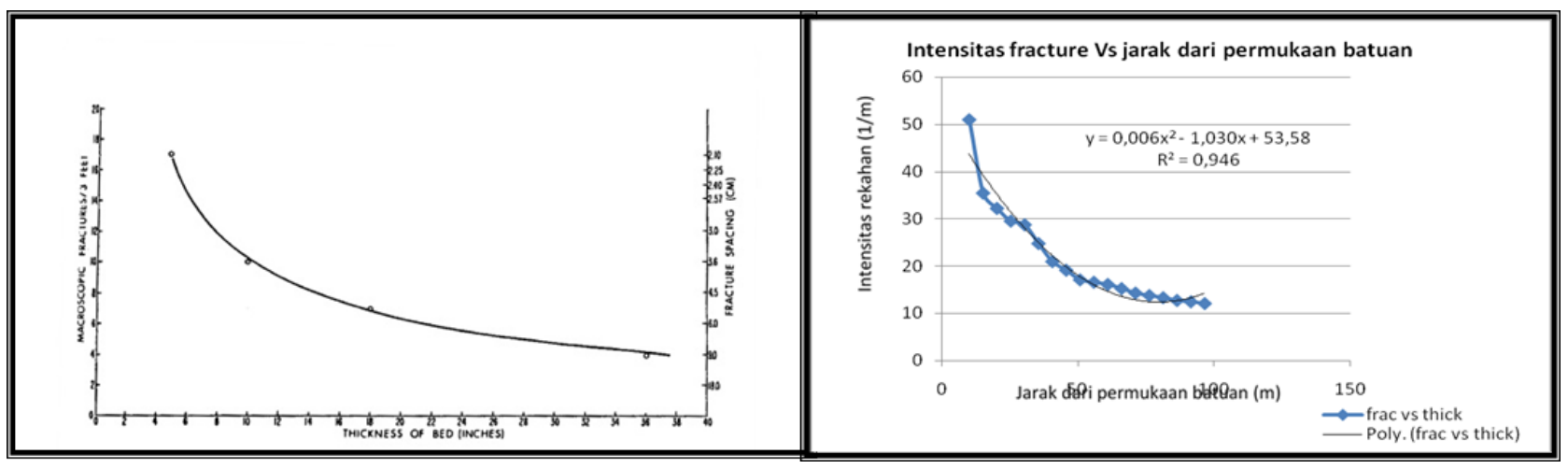

Gambar 9. Hubungan Tebal Lapisan/Jarak dari Permukaan Batuan Dengan Spasi Rekahan Dan Kurva Persamaan Garis Daerah Penelitian

(Price, 1966)

Berdasarkan persamaan hubungan jarak dari permukaan dan intensitas rekahan telah diaplikasikan ke dalam model 3 dimensi dan mendapat hasil berupa intensitas rekahan yang ditunjukkan dengan warna dan jarak nilai 0-1. 0 yang berarti intensitas rendah dan 1 yang berarti intensitas tinggi dapat dilihat pada Gambar 10.

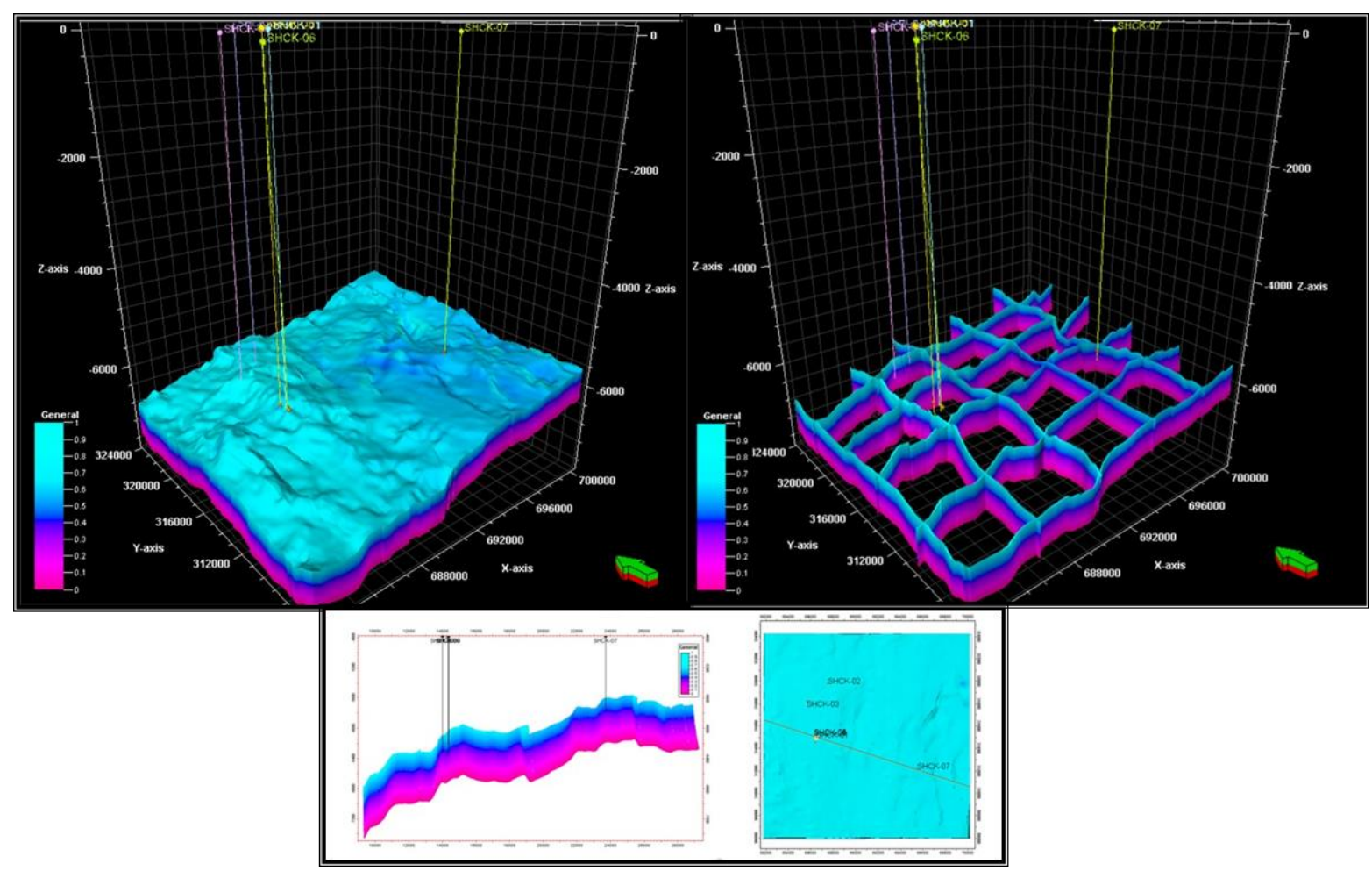

Gambar 10. Peta Dan Penampang Model Depth Related 


\section{PEMODELAN INTESITAS REKAHAN PADA FRACTURED BASEMENT RESERVOIR DENGAN PENDEKATAN KONSEP GEOLOGI MENGGUNAKAN ANALISIS KUALITATIF DI CEKUNGAN SUMATRA TENGAH}

\subsection{Intensitas total rekahan}

Intensitas total rekahan daerah penelitian merupakan hasil penggabungan intensitas rekahan dari ke empat model intensitas, yaitu seismik atribut ant tracking, hubungan dengan sesar/fault related, hubungan dengan lipatan/ fold related dan hubungan dengan jarak dari permukaan batuan. Nilai intensitas rekahan ditunjukan dengan warna dan jarak nilai 0-1. 0 yang berarti intensitas rendah dan 1 yang berarti intensitas tinggi dapat dilihat pada Gambar 11.

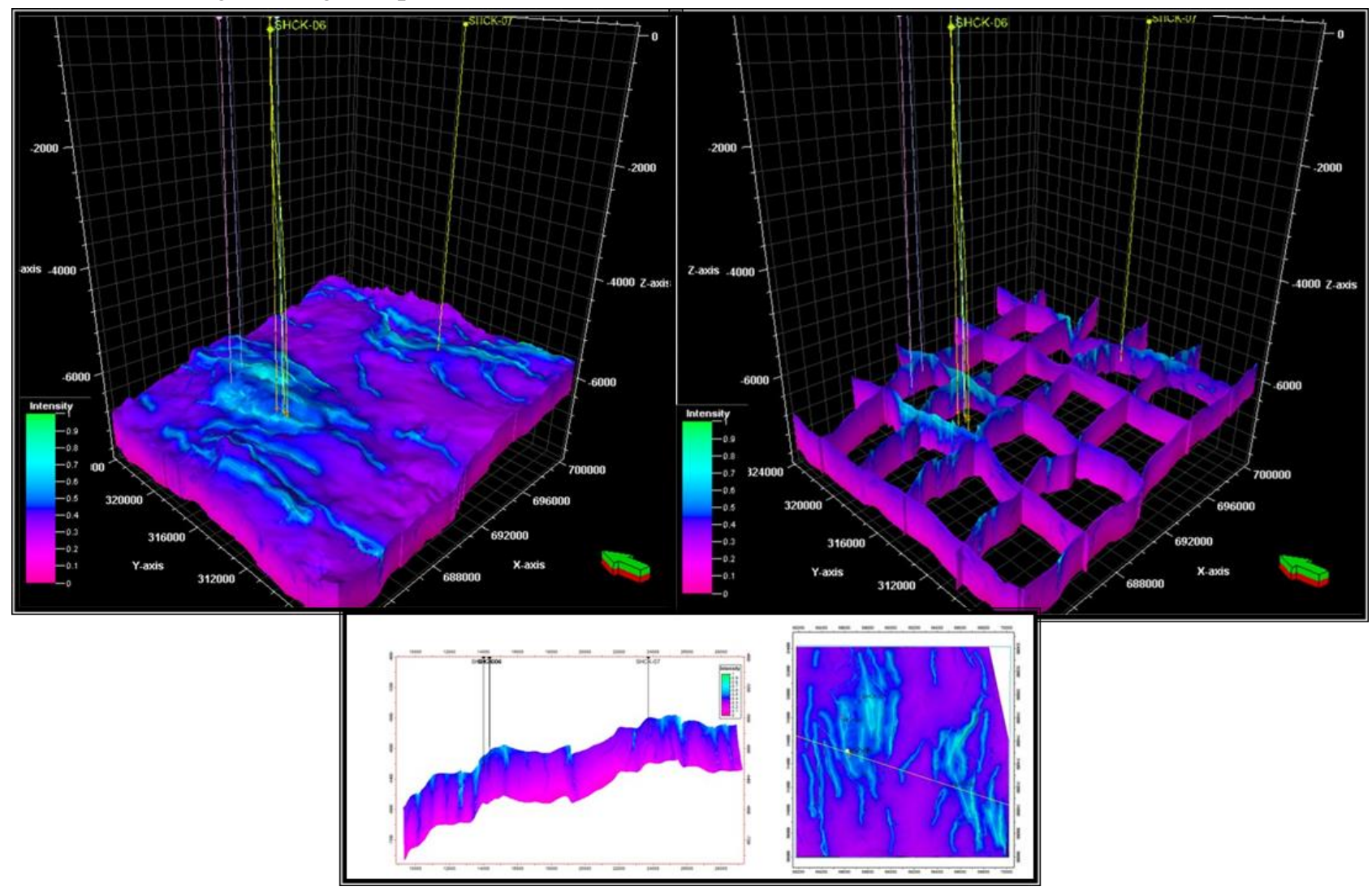

Gambar 11. Peta dan penampang intensitas total rekahan

\section{Kesimpulan}

Batuan dasar/Basement pada daerah penelitian merupakan batuan berumur Pra-Tersier yang didominasi litologi Kuarsit dan Philit. Secara umum batuan dasar pada daerah penelitian memiliki struktur sesar berarah umum Utara - Selatan \& Baratlaut - Tenggara yang sangat berpengaruh dalam pembentukan rekahan batuan dasar. Hasil pendekatan konsep geologi dan bantuan atribut seismik menghasilkan model intensitas dan distribusi rekahan dengan nilai 0 (tidak ada) hingga 1 (sangat tinggi). Daerah penelitian termasuk memiliki intensitas rekahan yang cukup tinggi dengan nilai antara $0,45-1$. Penelitian ini merupakan penelitian awal dalam penentuan zona potensi dan prospek reservoir fractured basement sehingga diperlukan penelitian lanjut yang lebih komperehensif.

\section{Daftar Pustaka}

Aguilera Roberto. 1995. Naturally Fractured Reservoirs. Pennwell Publishing Company, Tulsa, Oklahoma, United State of America. 540 hal

Dershowitz, B., LaPointe, P., Eiben, T. \& Lingli Wei. 2000. Integration of discrete feature network methods with conventional simulator approaches. SPE 62498

Guttorsmen Joel. 2010. Naturally fracture Basement Reservoirs: Using South Sumatra To Characterize The Challenges of Exploring And Exploiting Fracture Basement Resrvoirs . Proceedings of Indonesian Petroleum Association 34th, IPA 10-G-183, 15 hal

Heidrick. T. L., Karsani Aulia. 1993. A Structural and Tectonic Model of The Coastal Plains 
Block, Central Sumatra Basin. IPA Annual Convention, Indonesia.

K. J. W. Mc Caffrey, J. M. Sleight, S. Pugliese, R. E. Holdswoth. 2003. Fracture Formation And Evolution In Crystaline Rock : Insight From Atribute Analysis. Geological Society, London, Special Publication, 109124

Louis H. 1980. The Reservoirs Engineering Aspect Of Fracture Formation. Institut Francais $\mathrm{Du}$ Petrole, Ecole Nationale Superiure Du Petrole Et Des Moteurs, Paris, France
Nelson R.A, 2001. Geologic Analysis Of Naturally Fractured Reservoirs. Gulf Publishing Company, Houston, Texas, United State of America, 350 hal

Stearns, D.W. \& Friedman, M. 1972. Reservoirs in fractured rocks. In: Kling, R.E. (ed), Stratigraphic oil and gas fields: Classification, exploration methods and case histories. American Assoc. Petroleum Geol. Publ., Mem. 16, 82-106.

Van Golf Racht. T.D. 1982. Fundamental of Fracture Reservoir Engineering. Elsevier Scientic Publishing Company, Amsterdam, Netherland 